\title{
Peranan Aplikasi Keuangan dan Website Pada Industri Kecil Batu Bata
}

\author{
Lisye Fitria*1, Irma Amelia Dewi², Arie Desrianty³, Alif Ulfa Afifah 4 \\ 1,2,3,4 Institut Teknologi Nasional Bandung \\ e-mail: ${ }^{1}$ lisye@itenas.ac.id, 2irma_amelia@itenas.ac.id, \\ 3adesrianty@itenas.ac.id, ${ }^{4}$ ulfa.afifah@itenas.ac.id
}

\begin{abstract}
Abstrak
Kawasan Nagreg merupakan kawasan sentra produksi bata yang cukup terkenal, dimana beberapa penduduknya menjadikan produksi batu bata menjadi mata pencarian utama. Proses pengelolaan keuangan industri kecil batu bata di kawasan Nagreg masih banyak yang bersifat konvensional/manual dan belum menggunakan perangkat lunak sistem keuangan untuk membantu proses pencatatan keuangan dalam bisnis batu bata. Selain itu, kegiatan pemasaran belum menggunakan media online sehingga konsumen masih terbatas. Aplikasi penyusunan laporan keuangan sederhana diharapkan bisa digunakan sebagai alat pengambil keputusan. Selain itu pembuatan website perusahaan dikembangkan untuk membantu perusahaan dalam bidang pemasaran. Hasil yang dicapai adalah aplikasi keuangan sederhana dan website bagi pengrajin batu bata. Penggunaan aplikasi keuangan dan website bisa dimanfaatkan untuk menentukan strategi pemasaran berbasis teknologi untuk meningkatkan daya saing
\end{abstract}

Kata Kunci: aplikasi keuangan, website, batu bata

\begin{abstract}
The district of Negreg is a well-known brick production center, where some people choose to produce brick as their main occupation. Most of the small brick industry financial management processes in the Nagreg area are still conventional or manual and have not yet used financial system software to assist the financial recording process in their business. In addition, the marketing activities have not yet used online media so that the number of customers is still limited. A simple financial report application is expected able to be used as a decision-making device. In addition, the company's website was developed to help the company in the marketing field. The result is a simple financial application and a website for brick craftsmen. The financial application and the website can be used to determine technology-based marketing strategies to increase competitiveness.
\end{abstract}

Keywords: financial applications, website, bricks

\section{Pendahuluan}

Jawa Barat merupakan kawasan sentra produksi bata yang cukup terkenal. Salah satu lokasi produksi batu bata adalah kawasan Nagreg yang merupakan salah satu sentra pengrajin batu bata merah dengan harga murah tetapi mempunyai kualitas 
yang cukup baik. Pembuatan batu bata di kawasan ini masih dikerjakan secara manual. Munculnya pengrajin batu bata di kawasan Nagreg memiliki peran strategis dalam peningkatan pendapatan dan kesempatan kerja, penanggulangan kemiskinan, dan perluasan lapangan kerja di Indonesia. Penduduk di daerah Nagreg telah mampu memanfaatkan sumber daya alam yang ada di sekitarnya untuk dijadikan sebagai mata pencahariannya. Beberapa masyarakat sudah menjadikan produksi batu bata menjadi mata pencarian utama.

Bata merah atau batako menjadi bahan utama selain semen dan pasir untuk mendirikan bangunan. Proses pembuatan batu bata merah tergolong sangat mudah, dengan bahan baku tanah lempung, dan air, serta proses pembuatan yang dapat dilakukan secara manual. Hal ini yang menjadikan banyak masyarakat yang memilih untuk berprofesi sebagai pengrajin batu bata merah karena proses pembuatannya cukup sederhana, mulai dari mengaduk tanah, mencetak, dan proses menjemur, Deismasuci, dkk (2016). Proses yang sederhana menjadikan modal yang harus dikeluarkan tidak terlalu besar.

Laporan keuangan itu sangat diperlukan untuk mengukur hasil usaha dan perkembangan perusahaan dari waktu ke waktu dan untuk mengetahui sudah sampai dimana perusahaan untuk mencapai tujuannya. Proses pencatatan keuangan di industri kecil batu bata di kawasan Nagreg masih banyak yang bersifat konvensional/manual. Para Pelaku Usaha harus membuat laporan keuangan sebagai bentuk pertanggung jawaban aktivitas yang dilaksanakan, Hapsari, dkk (2019).

Masih banyak UMKM yang belum memanfaatkan aplikasi laporan keuangan untuk membantu proses pencatatan dan evaluasi keuangan, Rahmayuni (2017). Aplikasi keuangan sederhana dapat memudahkan bisnis berskala kecil dan menengah untuk membuat laporan keuangan di tengah tingginya tingkat persaingan. Informasi keuangan dapat disajikan dengan mudah dengan meng-input data transaksi ke dalam aplikasi keuangan.

Selain pembuatan laporan keuangan, kebutuhan untuk memasarkan produk batu bata sangat penting. Keberadaan media online dapat menyajikan berita secara cepat dan tepat tanpa terkendala waktu. Media online dapat membantu para pengrajin batu bata dalam memasarkan produk langsung kepada konsumen sehingga berdampak pada peningkatan penjualan. Media online berguna untuk para pengrajin dalam memasarkan produknya dengan biaya yang murah, mudah, dan sederhana.

Setiap perusahaan dan masyarakat menggunakan internet untuk keperluan bisnis atau sekedar hiburan. Indonesia merupakan salah satu negara dengan pengguna internet tertinggi di dunia. Hingga tahun 2017, pengguna internet di Indonesia mencapai 112,6 juta, Setti \& Wanto (2018). Di sisi lain, masih banyak juga usaha kecil yang belum memanfaatkan media online untuk mengiklankan produknya, sehingga pasarnya sangat terbatas. Terdapat kesenjangan antara bisnis yang menggunakan internet untuk mengiklankan produknya dan bisnis dengan pemasaran tradisional. Pemasaran tradisional akan sangat bergantung pada koneksi perusahaan tersebut. 
Internet memberikan peluang tambahan untuk memperbaiki citra dan reputasi perusahaan atau organisasi, Prayudi (2013).

Lingkup kegiatan pengabdian kepada masyarakat ini adalah pembuatan aplikasi pencatatan keuangan serta pembuatan website bagi pengrajin batu bata. Diharapkan dengan adanya keberadaan aplikasi keuangan dan website company profile yang dapat diakses oleh semua orang, khususnya orang Indonesia, dapat meningkatkan produktivitas industri kecil yang berada di kawasan Nagreg.

\section{Metode}

Metode untuk menghasilkan aplikasi laporan keuangan dan website sesuai dengan kebutuhan dilakukan melalui wawancara, diskusi, serta pelatihan. Sejak adanya pandemi Covid-19 semakin banyak Usaha Mikro Kecil, dan Menengah (UMKM) yang harus melakukan transformasi digital. Aplikasi program keuangan bisa membantu para pengrajin untuk mengetahui berbagai hal dalam mengelola dan memonitor segala bentuk laporan keuangan. Produktivitas para pengrajin batu bata akan jauh meningkat dengan memanfaatkan aplikasi akuntansi. Bentuk laporan keuangan akan disajikan dalam bentuk sederhana sehingga memudahkan pengrajin batu bata dalam menginputkan data dan membuat laporan. Selain itu, keberadaan aplikasi keuangan bisa membantu para pengrajin untuk mendapatkan permodalan usaha ke pemerintah/bank.

Di samping ketersediaan aplikasi keuangan, peranan website akan membantu perusahaan untuk memperkenalkan produknya. Ketersediaan website bisa memperkenalkan produk tanpa melihat keterbatasan jarak dan waktu. Jumlah konsumen yang selama ini terbatas dan dilakukan melalui cara dari "mulut ke mulut" akan mengalami peningkatan karena memanfaatkan fungsi media online.

Kegiatan dilaksanakan pada bulan September sampai dengan bulan November 2020. Kondisi pandemi mengakibatkan kegiatan banyak dilakukan melalui media online dan diskusi terbatas di lapangan. Hasil dari aplikasi keuangan dan website dibuat dengan melihat kebutuhan lapangan. Mahasiswa dilibatkan dalam membantu pembuatan website.

Pelaksanaan pengabdian kepada masyarakat dilaksanakan di Kampung Durung Kidul Desa Bojong Kecamatan Nagreg Kabupaten Bandung. Berdasarkan Badan Pusat Statistik Kabupaten Bandung (2019) terdapat jumlah industri batu bata seperti pada Tabel 1.

Berdasarkan tabel 1, dapat dilihat bahwa wilayah Bojong mempunyai industri batu bata terbanyak. Berdasarkan hasil pengamatan di lapangan, rata-rata industri batu bata yang ada di kawasan Bojong tergolong industri rumah tangga dengan kategori kecil dan menengah. Rata-rata industri batu bata yang ada merupakan industri yang dilakukan secara turun temurun. 
Tabel 1. Jumlah Industri dan Kerajinan Rumah Tinggi

\begin{tabular}{|c|l|c|c|c|c|}
\hline No & \multicolumn{1}{|c|}{ Desa/Kelurahan } & $\begin{array}{c}\text { Industri } \\
\text { bata }\end{array}$ & $\begin{array}{c}\text { Industri } \\
\text { tenun }\end{array}$ & $\begin{array}{c}\text { Industri } \\
\text { kuliner }\end{array}$ & $\begin{array}{c}\text { Industri } \\
\text { lainnya }\end{array}$ \\
\hline 1 & Mandalawangi & 1 & 0 & 1 & 0 \\
\hline 2 & Bojong & 324 & 0 & 0 & 0 \\
\hline 3 & Ciherang & 0 & 2 & 0 & 7 \\
\hline 4 & Ciaro & 3 & 0 & 0 & 0 \\
\hline 5 & Nagreg & 30 & 0 & 0 & 3 \\
\hline 6 & Citaman & 24 & 0 & 0 & 0 \\
\hline 7 & Nagreg Kendan & 30 & 0 & 3 & 0 \\
\hline 8 & Ganjarsabar & 7 & 0 & 3 & 0 \\
\hline & & 419 & 2 & 7 & 10 \\
\hline
\end{tabular}

Tahap awal yang dilakukan pada kegiatan ini adalah pemilihan industri untuk menerapkan aplikasi keuangan dan pembuatan website. CV. Rian dipilih sebagai sampel untuk penerapan aplikasi laporan keuangan dan pembuatan website. Pemilihan didasarkan kepada ketersediaan sumber daya manusia yang mampu untuk menerapkan sistem laporan keuangan dan pengelolaan website.

\section{Pembuatan Aplikasi Laporan Keuangan}

Dalam praktiknya laporan keuangan oleh perusahaan tidak dibuat secara serampangan, tetapi harus dibuat dan disusun sesuai dengan aturan atau standar yang berlaku, Kasmir (2012). Hal ini dilakukan agar laporan keuangan mudah dibaca dan dimengerti. Pencatatan yang terdokumentasi dengan baik sangat diperlukan agar perusahaan mendapat informasi penting untuk menjaga dan mengembangkan bisnisnya. UMKM harus melakukan pencatatan keuangan diantaranya catatan arus kas, laba rugi, dan neraca. Adanya pencatatan keuangan mengakibatkan perusahaan dapat membandingkan kondisi finansial setiap tahun.

Keuangan diartikan sebagai seni dan ilmu mengelola uang, artinya keuangan adalah seni dan sains. Keuangan adalah ilmu yang matang karena memberikan pengetahuan tentang bagaimana dan kapan perusahaan harus berinvestasi untuk melampaui perusahaan lain, Gittman \& Zutter (2015).

Selain itu, keuntungan penggunaan perangkat lunak aplikasi laporan keuangan adalah:

a. Menghemat banyak waktu dan tenaga karena dengan sistem akuntansi yang terkomputerisasi, pencatatan dokumen bisnis bisa dilakukan secara bersamaan.

b. Catatan semua transaksi dapat diolah menjadi laporan keuangan menjelang akhir tahun untuk tujuan penilaian kinerja, kebutuhan audit, dan kebutuhan administrasi lainnya.

c. Perangkat lunak sistem keuangan sebagai alat perencanaan ini dapat membantu untuk meminimalisasi timbulnya piutang tak tertagih dan segala denda keterlambatan dari pelunasan utang.

d. Meminimasi kesalahan dalam menghitung nominal angka pada invoice atau kesalahan penulisan (typo). 
e. Semua proses pencatatan akan dikumpulkan dan dikonversi menjadi suatu data digital untuk selanjutnya disimpan dengan aman dan rapi secara otomatis oleh sistem. Jika ingin meninjau kembali suatu faktur atau invoice, bisa mencarinya dengan mudah hanya dengan mengetik nama pelanggan atau tanggal transaksi terjadi pada kolom pencarian.

Tahapan dalam proses pembuatan akuntansi sederhana yang dapat diberikan pada industri kecil adalah:

a. Pembuatan akun.

Akun dibuat untuk mempermudah perusahaan dalam memilih transaksi sesuai dengan elemen dalam laporan keuangan yang terdiri atas:

1) Saldo awal untuk akun.

2) Data produk yang dijual, dimana saat ini hanya batu bata.

3) Data konsumen atau pembeli yang terdiri atas pembeli langsung dan bandar.

4) Data pemasok untuk pembelian bahan baku.

5) Perhitungan aktiva tetap yaitu harta yang dimiliki oleh perusahaan dan digunakan untuk operasional perusahaan dengan manfaat lebih dari satu tahun.

b. Membuat buku Jurnal Umum.

Buku Jurnal Umum adalah buku yang mencatat semua jurnal atas transaksi, untuk selanjutnya mencatat ke dalam buku besar untuk mempersiapkan laporan keuangan berdasarkan daftar saldo pada akhir periode.

c. Pembuatan aplikasi laporan keuangan sederhana.

\section{Pembuatan Website}

Proses pembuatan website membutuhkan data perusahaan untuk mengisi konten yang sudah dirancang. Kebutuhan data didapatkan dari hasil wawancara dan diskusi dengan pihak kecamatan dan masyarakat. Setelah website selesai dikembangkan, pemilik CV. Rian dilatih secara mandiri untuk menggunakan website dan memasukkan data ke dalam website-nya. Materi yang diberikan selama pelatihan terkait tentang apa itu website, beberapa kegunaan website, penggunaan website sebagai alat digital marketing, membuat profil perusahaan, dan meng-update informasi.

Basis data adalah kumpulan kumpulan data yang terkait, disusun, dan disimpan secara sistematis dalam penyimpanan komputer mengacu pada metode tertentu sehingga dapat diakses dengan cepat dan mudah menggunakan program/aplikasi komputer untuk memperoleh data dari basis data, Ichwan (2011). Pembuatan website menggunakan database relasional dan menggunakan DBMS MySQL. Pengguna dari website ini dapat memanfaatkan menu diantaranya home page, gallery page, contact page, login page, dan admin page. Keberadaan website akan membantu pengrajin batu bata dalam hal pemasaran melalui:

a. Peningkatan kepercayaan konsumen sehingga membuat bisnis mereka lebih kredibel atau terpercaya. 
b. Pengelolaan dilakukan secara mandiri.

c. Penerbitan produk baru, kegiatan perusahaan, event perusahaan, ataupun artikel lainnya yang berkaitan dengan produk perusahaan.

\section{Hasil dan Pembahasan}

Pelaksanaan pengabdian kepada masyarakat dilakukan di Kampung Durung Kidul Desa Bojong Kecamatan Nagreg Kabupaten Bandung. Desa yang dikenal sebagai sentra penghasil bata merah karena sebagian besar penduduknya bermata pencarian sebagai pengrajin batu bata merah (bata cap O). Kesulitan dalam mendapatkan pekerjaan menjadikan sebagian besar masyarakat memilih untuk memproduksi batu bata yang keahlian itu sudah ada secara turun temurun.

Para pengrajin dapat mendirikan tempat produksi dengan mudah, karena bahan baku bisa diperoleh di sekitar wilayah produksi. Proses dilakukan secara manual dan sederhana, tidak memerlukan keterampilan khusus. Tahapan pembuatan batu bata terdiri atas: proses pengadukan tanah, pencetakan, pengeringan, dan pembakaran. Gambar tempat melakukan produksi batu bata terdapat pada Gambar 1.

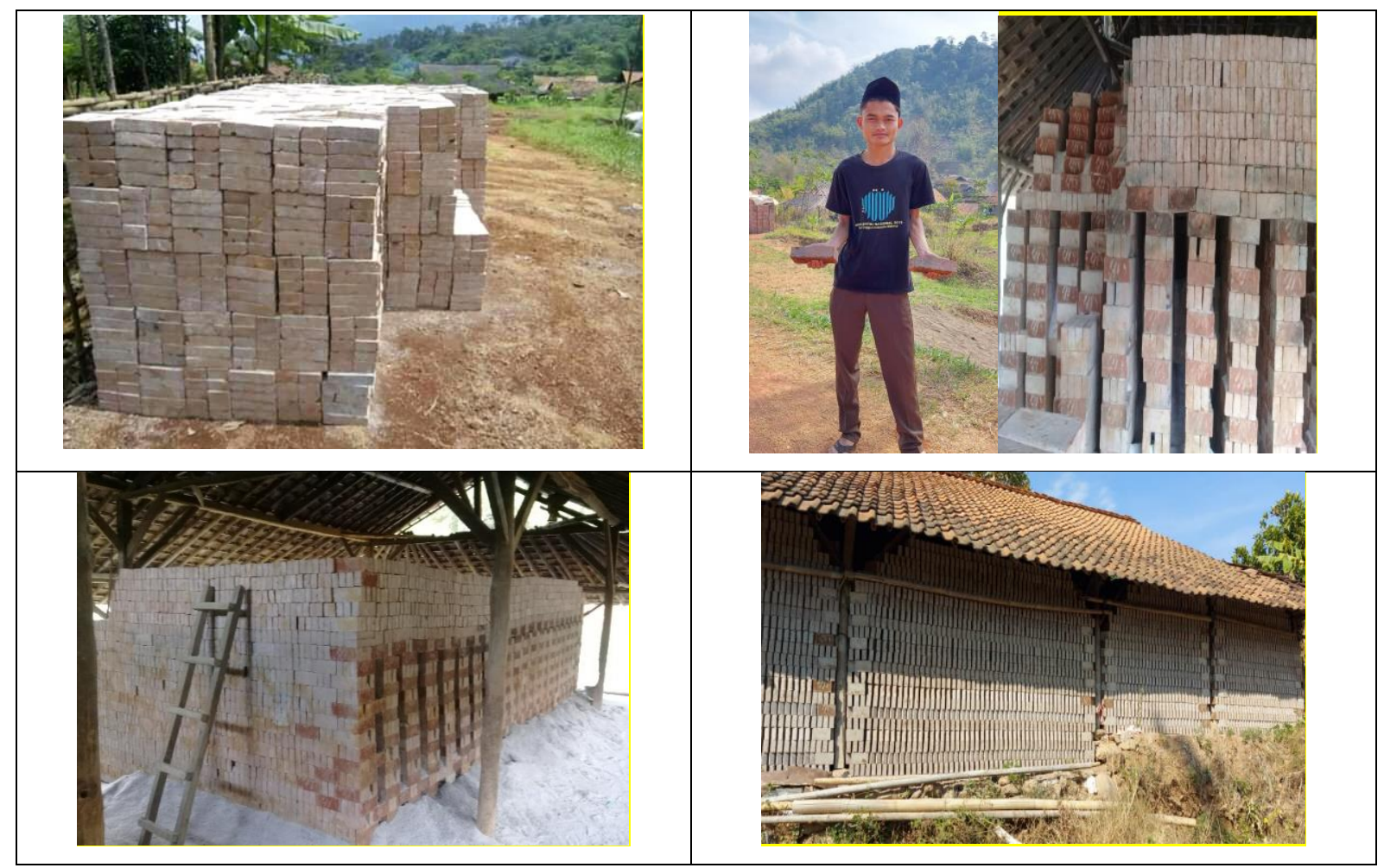

Gambar 1. Tempat pembuatan batu bata

Kegiatan pengabdian kepada masyarakat di kawasan industri batu bata terdiri atas pembuatan aplikasi keuangan sederhana dan pengembangan website untuk CV. Rian yang berlokasi di Kampung Durung Kidul Desa Bojong Kecamatan Nagreg Kabupaten Bandung. Hasil yang didapatkan dari kegiatan ini adalah: 


\section{Aplikasi Pengelolaan Keuangan CV. Rian.}

Jenis transaksi yang terjadi dalam proses pembuatan batu bata di CV. Rian tidak terlalu banyak karena jenis bahan baku yang sedikit, jumlah tenaga kerja terbatas, dan biaya investasi yang tidak terlalu besar. Aplikasi dibuat dengan menggunakan Visual Basic Application (VBA) dengan formulasi dari Microsoft Excel karena lebih mudah dipahami. Beberapa proses penggunaan dan pemasukan keuangan diantaranya adalah:
a. Biaya mengaduk tanah.
b. Biaya proses pencetakan tanah menjadi bata.
c. Biaya penetapan proses pengeringan bata.
d. Biaya penetapan bata kering.
e. Biaya pembuatan tungku dan pembakaran.
f. Pembelian bahan bakar untuk proses pembakaran.
g. Biaya pembongkaran tungku bata.
h. Biaya pengangkatan bata ke jalan.
i. Biaya lain lain.
j. Penjualan bata.

Setelah aplikasi selesai dibuat, selanjutnya dilakukan sosialisasi kepada CV. Rian mengenai proses pengisian data dalam pencatatan transaksi keuangan ke dalam jurnal dengan menempatkan mana akun yang didebet maupun yang dikredit. CV. Rian juga diberikan pengetahuan dan keterampilan bagaimana proses menyajikan laporan keuangan laba/rugi usaha. Tampilan cover aplikasi keuangan dapat dilihat pada Gambar 2.

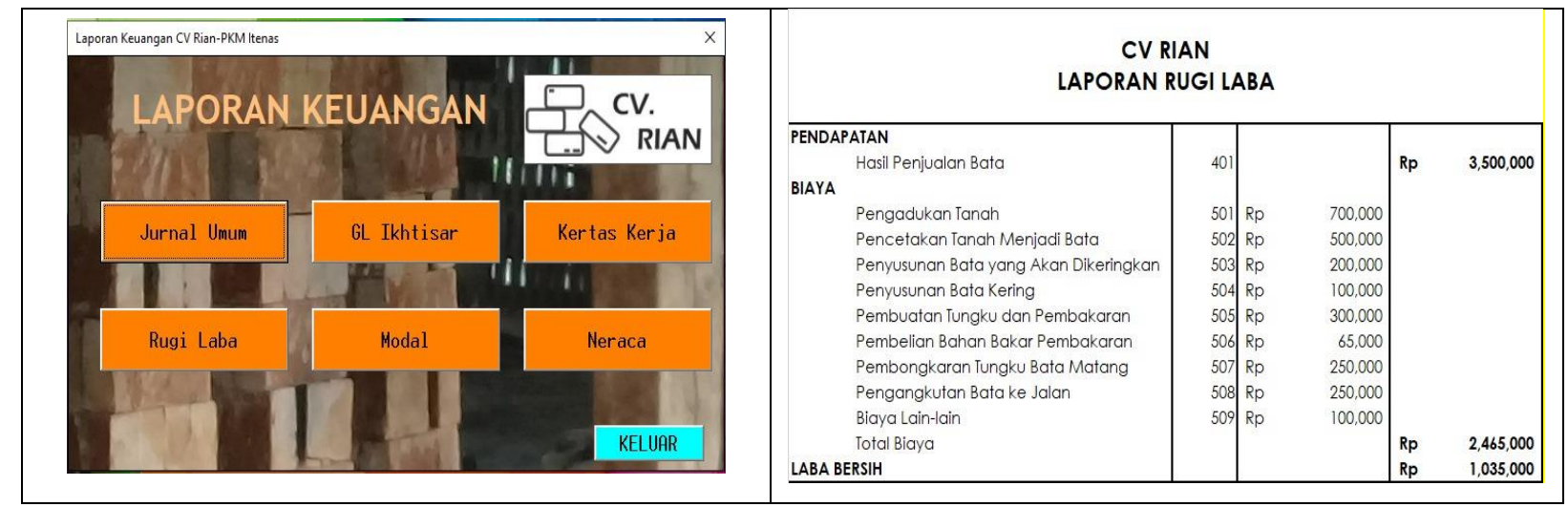

Gambar 2. Tampilan Aplikasi Laporan Keuangan

Hal hal yang menjadi permasalahan dalam implementasi laporan keuangan di kawasan Desa Bojong kecamatan Nagreg adalah:

a. Investasi ketersediaan komputer/laptop masih sulit karena masih banyak pengrajin yang miskin. Berdasarkan hasil wawancara dengan pengrajin, keuntungan yang didapatkan dari satu kali produksi adalah Rp 4,5 juta. Keuntungan itu didapatkan setiap 3 bulan sekali. Permasalahan ketersediaan komputer bisa diatasi dengan adanya bantuan pengadaan dari pihak luar/pemerintah. Pihak desa dapat mencari alternatif mitra, seperti perusahaan 
atau perguruan tinggi, yang dapat memberikan komputer yang sudah tidak up to date, karena kebutuhan aplikasi laporan keuangan tidak membutuhkan komputer dengan spesifikasi yang tinggi.

b. Masih sedikit pengrajin yang mempunyai kemampuan dalam mengoperasikan komputer. Masih ada pengrajin tidak melakukan proses pencatatan keuangan, sedangkan sebagian lagi memilih pencatatan keuangan secara manual. Hal ini yang menyebabkan pengrajin sulit untuk mendapatkan pinjaman dari bank atau bantuan pemerintah, karena tidak tersedianya laporan keuangan.

c. Hal yang bisa dilakukan untuk mengatasi permasalahan ini adalah bekerja sama dengan pihak desa untuk mengadakan pelatihan penyusunan laporan keuangan bagi industri kecil di kawasan industri batu bata Nagreg.

2. Website.

Perancangan website sebagai media promosi untuk CV. Rian yang terletak di Desa Bojong Kecamatan Nagreg terdiri atas halaman admin dan halaman utama. Halaman admin diantaranya terdiri atas form kategori, form produk, form order, form login, dan form slide yang hanya dapat dikelola oleh admin. Halaman utama website seperti form pemesanan, form detail produk, dan form kontak dapat dikelola oleh calon konsumen.

Hal-hal yang menjadi permasalahan dalam implementasi penggunaan website di kawasan Desa Bojong Kecamatan Nagreg adalah:

a. Jaringan internet di kawasan Desa Bojong Kecamatan Nagreg belum stabil. Hal ini bisa dipecahkan dengan kerja sama dengan pihak eksternal dalam meningkatkan kualitas jaringan di sekitar wilayah Desa Bojong.

b. Owner harus selalu melakukan pemutakhiran, pemantauan (penggunaan dan penampilan), serta pemeliharaan situs website sehingga data selalu up to date. Hal ini perlu disampaikan pada saat pelatihan.

Link untuk website CV. Rian adalah http://mfdzaky.my.id/CV-Rian/index.php dengan tampilan awal dapat dilihat pada Gambar 3.
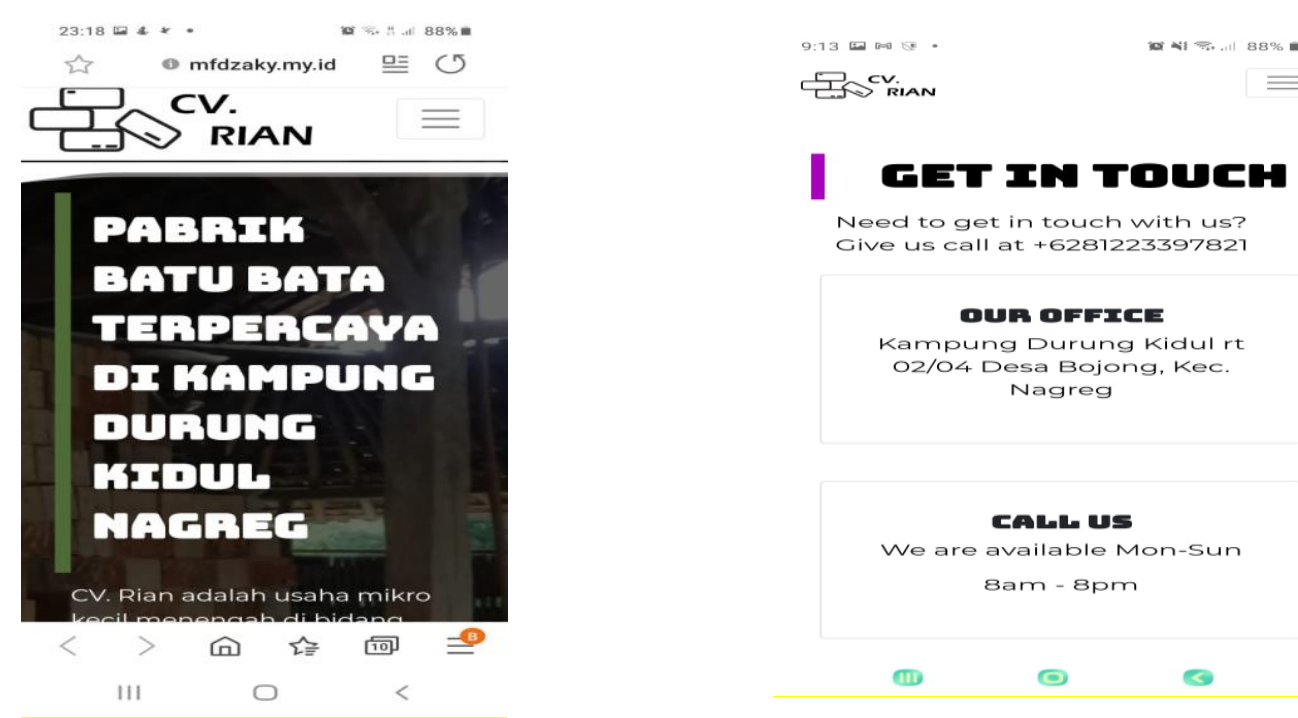

Gambar 3. Tampilan Website CV. Rian 


\section{Simpulan dan Rekomendasi}

Para pengrajin batu bata terbantu dengan adanya program keuangan sederhana. Aplikasi dibuat sederhana agar mudah untuk digunakan. Ketersediaan aplikasi laporan keuangan sederhana bisa membantu perusahaan untuk mendapatkan bantuan dana dari pemerintah atau dari investor lainnya. Permasalahan yang muncul untuk implementasi di kawasan Desa Bojong Kecamatan Nagreg untuk aplikasi laporan keuangan adalah keberadaan sarana komputer dan ketersediaan SDM yang mampu mengoperasikan aplikasi tersebut.

Pembuatan website adalah salah satu pendorong bagi para pengrajin di Desa Bojong untuk memasarkan produknya. Adanya aplikasi laporan keuangan sederhana dan ketersediaan website diharapkan akan meningkatkan kepercayaan konsumen sehingga membuat bisnis para pengrajin batu bata lebih kredibel sehingga produksi dan penjualan dapat meningkat.

\section{Penghargaan}

Penulis mengucapkan terima kasih kepada Lembaga Penelitian dan Pengabdian kepada Masyarakat Institut Teknologi Nasional (ITENAS) Bandung yang telah memberikan dukungan finansial sehingga kegiatan pengabdian pada masyarakat untuk pengrajin batu bata di kawasan Nagreg kabupaten Bandung dapat terselenggara dengan baik.

\section{Daftar Pustaka}

Badan Pusat Statistik Kabupaten Bandung (2019). Kecamatan Nagreg dalam Angka 2019. Bandung

Deismasuci, M., Rohmat, D., Malik, Y. (2016). Dampak Industri Bata Merah Terhadap Kondisi Lingkungan Di Kecamatan Nagreg. Antologi Pendidikan Geografi, 4 (2), 1-12. http://repository.upi.edu/26603.

Gitman, Lawrence J., and Chad J Zutter. (2015). Principles of Managerial Finance, Brief. University of Pittsburgh.

Hapsari, Dini Wahjoe., Pratomo, Dudi., Suryani, Elly. (2019). Mengelola Laporan Keuangan Para Pelaku Usaha pada PKBM Bina Mandiri Bandung. Jurnal Dinamisia. Jurnal Pengabdian Kepada Masyarakat, 3 (special issues), 59-66. https://doi.org/10.31849/dinamisia.v3i2.2840

Ichwan, M. (2011). Pemrograman Basis Data Delphi $7 \&$ MySQL. Informatika ITENAS Bandung

Kasmir. (2012). Analisis Laporan Keuangan. PT. Rajawali Pers. Jakarta

Prayudi. (2013). Manajemen Isu dan Tantangan Masa Depan: Pendekatan Public Relations. Jurnal Ilmu Komunikasi, 4(1), 25-39. https://doi.org/10.24002/jik.v4i1.229 
Rahmayuni, S. (2017). Peranan Laporan Keuangan Dalam Menunjang Peningkatan Pendapatan Pada UKM. Jurnal Sosial Humaniora Dan Pendidikan, 1(1), 93-99. DOI: https://doi.org/10.32487/jshp.v1i1.239

Setti, S., \& Wanto, A. (2018). Analysis of Backpropagation Algorithm in Predicting the Most Number of Internet Users in the word. JOIN, 110-111. 